\title{
THE DISTRIBUTION OF BATS ON THE ADRIATIC ISLANDS
}

\author{
by \\ BEATRICA DULIĆ \& NIKOLA TVRTKOVIĆ \\ Zoological Institute, Faculty of Natural Sciences and Institute of Biology of the University, \\ Zagreb, Yugoslavia
}

The bat fauna of the Adriatic islands is very poorly known in comparison with that of the coastal continental regions (Kolombatovic, 1882, 1884; Dulic, 1959). Although ten species of bats are recorded, the data for most of the islands except the island of Lastovo (Dulic, 1968) are scarce, and of an early date.

During the years 1966-1970, mostly in the summer (July, August), we investigated the bat fauna of some Adriatic islands, particularly of the southern ones. During 17 trips, each of 5 to 10 days, to 8 islands, 200 bats were collected and several hundreds were examined (caught in mist nets or taken in caves). The investigated area is shown in fig. 1, the distribution of the bats in table

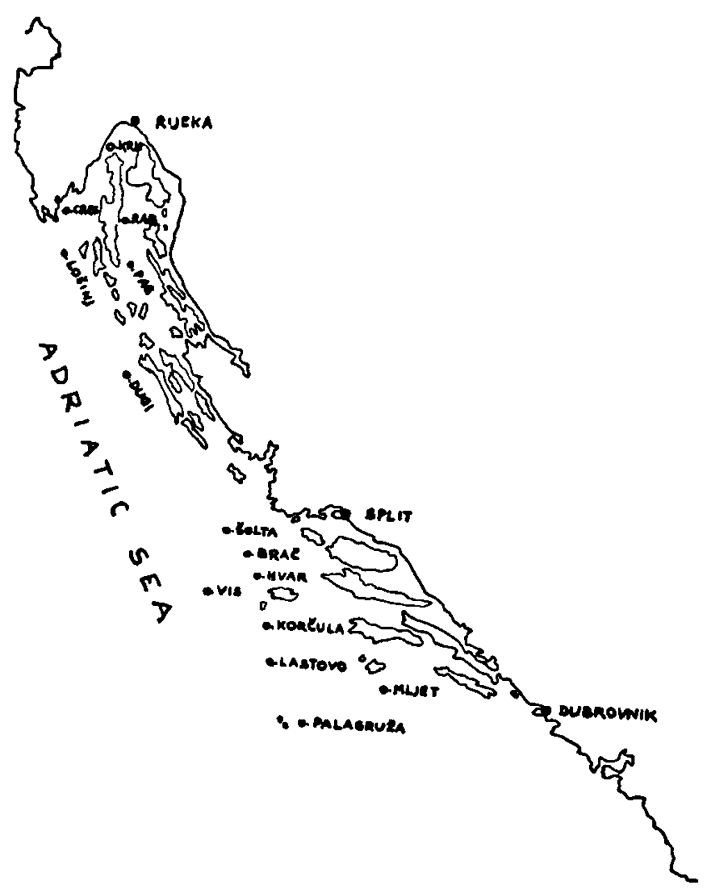

Fig. 1. The area investigated.
I. Bibliographical data included, 16 species of bats from the Adriatic islands (north, middle, and south) are known now.

\section{REMARKS ON DIFFERENT SPECIES}

Rhinolophus ferrumequinum ferrumequinum

(Schreber, 1774)

The Greater Horseshoe Bat is widely distributed on the islands. Colonies of about 80 to 150 animals inhabit the islands of Hvar, Vis, and Lastovo. They live in caves near the sea, even those partially flooded with sea-water (Hvar), but only during the summer. Most are nursing colonies, though in some of them (Lastovo) we found also males. Some isolated males we found on the same island in an abandoned church, and on the island of Mljet in crevices in stones above the sea. The colonies on the islands of Hvar and Lastovo were mixed with Miniopterus schreibersi, and on the island of Vis with Myotis emarginatus. On the island of Vis for instance we did not find a single bat in caves during the winter of 1970 , in spite of the careful research.

\section{Rhinolophus hipposideros (Bechstein, 1800)}

The subspecific status of the Lesser Horseshoe Bat is not considered in this paper. This bat was found in summer in small colonies of about 50 animals on the attic of a church in the town Dobrinj (Island of Krk), and in abandoned water pits (island of Korčula). Isolated specimens were observed in small caves on the island of Brač, and in rocks above the sea (island of Mljet). It is not uncommon.

Rhinolophus euryale euryale (Blasius, 1853)

The Mediterranean Horseshoe Bat was found only once, on the island of Korčula (Dulić, 1959). It seems to be rare on our islands, while it is quite common on the coastal mainland. 
Table I. Distribution of bats on Adriatic islands.

\begin{tabular}{|c|c|c|c|c|c|c|c|c|c|c|c|c|c|c|c|c|}
\hline Island & 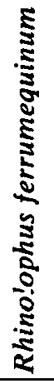 & 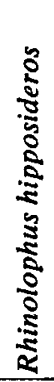 & 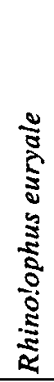 & 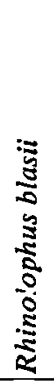 & 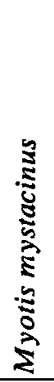 & 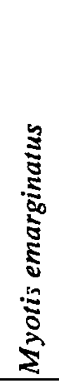 & 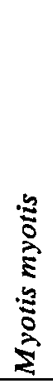 & 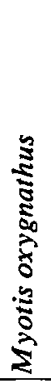 & 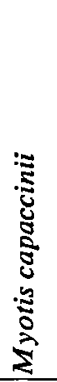 & 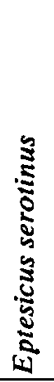 & 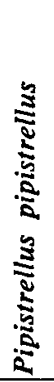 & 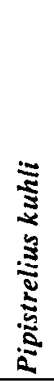 & 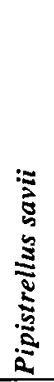 & 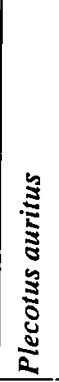 & 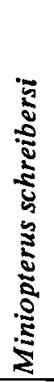 & 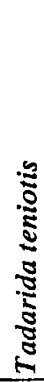 \\
\hline Krk & & + & & & & & & $\bullet$ & & & + & + & & & - & \\
\hline Solta & & & & & + & & & & & & & $\bullet$ & + & - & & $\bullet$ \\
\hline$\overline{\text { Brač }}$ & 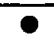 & 0 & & & + & & & $t$ & & & 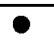 & $\bullet$ & $t$ & 0 & & \\
\hline Hvar & $\bullet$ & & & & + & & & & & & & + & 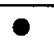 & + & + & \\
\hline Vis & + & & & & & + & & & & & & + & + & & & \\
\hline Korčula & + & + & $\bullet$ & & + & + & $?$ & & & & $\bullet$ & + & + & + & & + \\
\hline Lastovo & $\bullet$ & & & $\bullet$ & $\bullet$ & & & & & $\bullet$ & $\bullet$ & 0 & $\bullet$ & $\bullet$ & $\bullet$ & \\
\hline$\overline{\text { Mljet }}$ & 0 & + & & & + & & $?$ & & & & & $\bullet$ & $\bullet$ & + & $\bullet$ & \\
\hline
\end{tabular}

+ own record; 0 data from the literature.

Rhinolophus blasii (Peters, 1866)

Some 30 Blasius Horseshoe Bats were found in a cave on the island of Lastovo. There are no data from the other islands.

\section{Myotis mystacinus mystacinus (Kuhl, 1819)}

The very common occurrence of Whiskered Bat on the islands is in agreement with Kolombatovic $(1882,1884)$. However, our records are the first for most islands in the southern Adriatic. Our specimens were captured in the summer above the different drinking places (Dulić, 1970).

Myotis emarginatus emarginatus (Geoffroy, 1806) This bat is a new to the Adriatic islands. Kolombatovic $(1882,1884)$ considered it to be rare in Dalmatia, but according to our investigations it is quite common. It was captured on the island of Korčula, in mist nets above water pools near a pine wood, and near a village. On the island of Vis colonies live in summer in marine caves together with $R h$. ferrumequinum; in winter there are no bats in such caves. The present record supplements the findings of Van Laar \& Daan (1964) on the islands in the eastern Mediterranean.

\section{Myotis myotis myotis (Borkhausen, 1797)}

The Large Mouse-eared Bat was observed but not caught in the caves of islands of Korcula and Mljet. Data on its distribution are very scarce, the species does not seem to be common.
Myotis oxygnathus (Monticelli, 1885)

The Lesser Mouse-eared Bat was known to occur on the North Adriatic island of Krk (Miric, 1968). It is recorded here for the first time (in some 100 specimens) from the southern Adriatic (island of Brač). Its habitat on the island of Krk is a marine cave, and on Brač a tower of a high church in the town of Milna. It is widely distributed on coastal mainland (Dulic, 1961). On the island of Krk it occurs together with Miniopterus schreibersi in the cave near Baška.

Myotis capaccinii capaccinii (Bonaparte, 1837)

The single specimen of Long-fingered Bat caught on the island of Lastovo (Rača cave, Dulic, 1959) learns us nothing about its distribution on the Adriatic islands.

Eptesicus serotinus serotinus (Schreber, 1774)

Although the Serotine Bat is not uncommon on the coastal mainland, we were able to record it from the island of Korčula only (Dulić, 1959). We observed it in flight in the villages, and above waterpools.

\section{Pipistrellus pipistrellus pipistrellus (Schreber,} 1774)

Contrary to the following two species of this genus, the Common Pipistrelle seems to be rather rare. A small number of specimens was captured. We were unable to check the material from Kolombatović's collection. 
Pipistrellus kuhli kuhli (Kuhl, 1819) and Pipistrellus savii savii (Bonaparte, 1837)

Kuhl's Pipistrelle and Savi's Pipistrelle, in particular the second one, are the most common species on the islands in the southern Adriatic. For details on its ecology see Dulic $(1958,1970)$.

\section{Plecotus auritus auritus (Linnaeus, 1758)}

The Long-eared Bat was known from several islands, and is now recorded from two more: Korčula and Mljet. In the first of these, it inhabits (together with $R h$. ferrumequinum) a stony region of a peculiar physiography: old trees of Quercus ilex are scattered among great stone blocks and subterranean pot-holes. It was found near the villages and olive-groves too. In the small town Jelsa on the island of Hvar, 15 to 20 animals formed a nursing colony in July 1968 under the roof of the church. The Long-eared Bat is common on the south Adriatic islands. Balcells (1963) considered it probable that the Long-eared Bats from the greater part of Yugoslavia and from the Adriatic islands were Plecotus austriacus. Our material, except one specimen from the island of Korčula, has the measurements of $\boldsymbol{P}$. auritus (see Van Bree \& Dulic, 1963).

\section{Miniopterus schreibersi schreibersi (Kuhl, 1819)}

Colonies of Long-winged Bat, counting 50 to 150 and more specimens, together with nursing colonies of $R h$. ferrumequinum, were found in marine caves, one of them on the island of Lastovo, the other on the island of Hvar. This bat was found also with $M$. oxygnathus in a marine cave on the island of Krk. According to our data the Longwinged Bat does not seem to be rare on the Adriatic islands. Earlier data (Klaptocz, 1908) mentioned the Long-winged Bat from the cave Ostaševica on the island of Mljet.

\section{Tadarida teniotis teniotis (Rafinesque, 1814)}

The European Free-tailed Bat has been recorded previously only once from the Adriatic islands (island of Solta, Kolombatovic, 1887). A new locality was found near the village Cara (island of Korčula), where four males were caught on 21 and 26 July 1969 during the night in mist nets above a pool. High rocks nearby are known as the habitat of this bat.

\section{GENERAL DISCUSSION}

Although it is highly probable that further investigations will yield some additional bats species from the Adriatic islands, the present data give us a fairly good picture of their bat fauna. As expected, most of the species found on islands occur also in the neighbouring coastal regions; this fact could not be ascertained for Tadarida teniotis whose distribution on the mainland is imperfectly known. The data from our investigations contribute to the knowledge of bat fauna for islands of Korčula and Vis from where almost nothing about bats was known. For some other islands (Brač, Hvar, and Mljet) the existing information is completed. Contrary to the earlier data for the Dalmatian coastal region (Kolombatovic, 1882, 1884), Myotis emarginatus seems to be common, and is here recorded for the first time from the Adriatic islands. Myotis oxygnathus, a common species in the coastal region, was also observed on the south Adriatic islands for the first time. The scarcity of Myotis myotis on the Adriatic islands is remarkable, because of its abundance in caves on the Dalmatian coast (Dulic, 1961). The situation is similar in Rhinolophus euryale whose colonies occur in some parts of Dalmatian coastal mainland. The causes of this pattern are at present unknown.

It is noteworthy that on some Adriatic islands, such as Lastovo, Vis, and Hvar, larger colonies of some species inhabit marine caves in summer (see Kahmann et al., 1956, for Corsica). We did not have the possibility to check whether the bats inhabit the caves on Lastovo and on Hvar in winter also, but we checked this on Vis, and found the caves in winter quite empty. The temperature of those caves (we visited 9 marine caves and 4 caves in inland of the island of Vis) varied in January 1970 from $14^{\circ}$ to $16^{\circ} \mathrm{C}$, and is nearly the same as outside. Thus the temperatures are higher than in the caves of Pietrabello and Sabara on Corsica where Kahmann et al. (1956) found winter colonies of Miniopterus schreibersi and rhinolophid bats. It is highly probable that high temperatures on the one hand and small size of most of those caves on the other cause the winter migration from such caves, or perhaps only from superficial parts into deeper crevices of the rocks. It is not known whether the bats inhabit some other habitat on the same island. Further, we were not able to collect data on microclimate of those caves, and of those on Lastovo and Hvar, in summer. Some of these caves were difficult to enter. The marine caves 
visited have the entrance open to the South. The distribution of bat cave fauna on the island of Vis in winter is similar to the situation in the coastal region with the exception that in Dalmatia (Dulic, 1961) some caves are inhabited by Rhinolophus blasii.

According to our opinion, one of the conditions favoring the distribution of bats on Adriatic islands especially the gregarious species, is the number of drinking places (Dulić, 1970). Furthermore the occurrence and the situation of marine caves favor the roost of nursing colonies. The local climate and the absence of strong winds may be important factors for the distribution and the number of bats. In the islands exposed to winds from the mainland (island of Brač) smaller numbers of bats were observed.

Further investigations of the bat fauna from the islands of the Adriatic Sea, and especially from its central part, seem useful.

\section{BIBLIOGRAPHY}

Balcells, E. R., 1963. Datos españoles de "Plecotus" y "Eptesicus" (Chir. Vespertilionidae). Miscelanea zool., 1 : $147-162$.

Bree, P. J. H. van \& B. Dulić, 1963. Notes on some specimens of the genus Plecotus Geoffroy, 1818 (Mammalia, Chiroptera) from the Netherlands. Beaufortia, 10 (113) : 7-18.

Dulıč, B., 1959. Beitrag zur Kenntnis der geographischen Verbreitung der Chiropteren Kroatiens. Glasnik Prir. Muz., (B) 14: 67-112.

-, 1961. Contribution à l'étude de la répartition et de l'écologie de quelques chauves-souris cavernicoles de Dalmatie. Mammalia, 25 : 287-313.

一, 1968. Istraživanja utjecaja biotopa na rasprostranjenje malih sisavaca na otoku Lastovu. Ljetopis Jug. Akad. znan. umj., 72 : 401-404.

,- 1969 . The distribution of some mammals on the islands of the Adriatic Sea from the ecological point of view. 3 Kongres biol. Jugosl. Knjiga plen. ref. in povz.: 301 .
-, 1970. Okologische Beobachtungen der Fledermäuse der Adriatischen Inseln. Z. Säugetierkd., 35 : 45-51.

Kahmann, H. \& P. Goerner, 1956. Les Chiroptères de Corse. Mammalia, 20 : 333-389.

KLAPTOCZ, B., 1908. Die zoologische Reise des naturwissenschaftlichen Vereins nach Dalmatien im April 1906, B. Spez. Teil, 5. Säugetiere. Mitt. natw. Ver. Univ. Wien, 6 (4) : 54-57.

Kolombatović, J., 1882. Mammiferi, anfibi e rettili e pesci rari e nuovi per l'Adriatico catturati nelle acque di Spalato. Izv. realke Splitu, 1881/82: 3-35.

-, 1884. Aggiunte ai vertebrati. Izv. realke Splitu, 1883/ $84: 6-28$.

-, 1887. Aggiunte ai Chirotteri della Dalmazia. Glasnik Hrv. nar. dr., 2 : $4-6$.

LAAR, V. vaN \& S. DAAN, 1964. On some Chiroptera from Greece. Beaufortia, 10 (120) : 158-166.

Mirić, D., 1968. Eine neue Apodemus-Art (Muridae, Mammalia) von der Insel Krk, Jugoslawien. Z. Säugetierkd., 33 : $369-376$. 